\title{
Practical application of the
} progesterone $\mathrm{P} 4$ rapid test in cow's milk for early pregnancy detection

\author{
B. Mehmedi, R. M. Gecaj*, T. Kastrati, M. Heltai and L. Turmalaj
}

\begin{abstract}
Pregnancy diagnosis is an essential part of fertility management in cattle. Early detection of pregnancy 21 days after artificial insemination (AI) allows for early recognition and rebreeding of non-pregnant animals with a minimum delay, which benefits the economic interest for farmers. Rapid progesterone $\mathrm{P} 4$ tests are widely used in fertility management strategies, yet there is limited data about the efficiency of tests for P4 measurements in cow's milk. By measuring P4 concentrations in the milk of different breeds: Red Holstein, Black-Holstein, Simmental, and local crossbreeds, this study aimed to assess the practical application and efficiency of an early and rapid pregnancy detection test from cow's milk. The study was conducted in 2017-2018 and milk samples were taken from animals at day 21 after artificial insemination (AI) to diagnose pregnancy. The test indicated that of the total cows $(n=400)$ included in
\end{abstract}

this study, 69\% were pregnant and 31\% were not pregnant, as interpreted based on the P4 Rapid (Ridgeway Science UK) test results. Accuracy of the early diagnosis was verified 60 days after $\mathrm{AI}$ (without further AI of cows) by rectal palpation. Based on this examination, $263(66 \%)$ cows were diagnosed as pregnant, while $14(34 \%)$ were diagnosed as non-pregnant. The highest accuracy in pregnancy detection was found in the local crossbreeds and the Simmental breed, with $97 \%$ correct diagnosis of cows, followed by Red Holstein with $94 \%$ and Black Holstein with an accuracy of $90 \%$. This study showed that the use of progesterone P4 rapid tests in milk samples is an effective, fast and accurate method for the early detection of pregnancy in cows, with an accuracy rate of 90 to $97 \%$ based on cattle breed.

Key words: artificial insemination; pregnancy; screening test; rectal examination

Blerta MEHMEDI, DVM, PhD, Research and Teaching Assistant, Rreze M. GECAJ*, PhD, Assistant Professor, (Corresponding author, e-mail: rreze.gecaj@uni-pr.edu), Department of Biotechnology in Zootechny, University of Prishtina, Faculty of Agriculture and Veterinary, Republic of Kosova; Taulant KASTRATI, DVM, PhD, Director of Veterinary Service, Kosova, Republic of Kosova; Miklós HELTAI, PhD, Full Professor, Faculty of Agricultural and Environmental Sciences, Szent István University, Hungary; Luigj TURMALAJ, DVM, PhD, Full Professor, Faculty of Veterinary Medicine, Agricultural University of Tirana, Albania 


\section{Introduction}

The cow's ability to reproduce is essential for milk production and is a key factor for cost efficiency in the dairy industry. Many new and old technologies are available to identify pregnant and nonpregnant animals and can play a key role in an overall reproductive management strategy to rapidly return these animals to the breeding programme (Crowe et al., 2018; Szenci et al., 2018). Detecting open cows is the most important aspect of pregnancy diagnosis. The economic benefits of pregnancy diagnosis depend on several factors, such as time after insemination when the diagnosis is performed, accuracy of the diagnosis, its effect on embryonic loss, efficiency of oestrus detection, and measures taken when cows are found to be open. Earlier pregnancy diagnosis decreases the time to re-insemination of cows found open, which reduces expected days open for those cows (Cabrera, 2014; Đuričić et al., 2020a). Early identification of pregnant and non-pregnant cows post-breeding improves reproductive efficiency and pregnancy rate in cattle by decreasing the interval between services. It is also key to shortening the calving interval period, which is of the utmost importance in animal management for economic reasons (Purohit, 2010; Kleczkowski et al., 2017). Pregnancy diagnosis has become a routine tool in the reproductive management of dairy cows (Fricke, 2002; Kočila et al., 2009). Traditionally, producers have relied on veterinarian palpation of cows after 35 days of gestation or ultrasound examination after day 28 (Romano et al., 2006). The accuracy of these conventional methods depends on the practitioner's experience, and the gestational stage, age and body condition score of the animal (Youngquist, 2007). Parkinson et al. (1994) stated that during the sexual cycle, progesterone levels reach their peak at 13-14 days after oestrus.
If the cow is pregnant, progesterone levels will rise continually up until 21 days after fertilization. Accordingly, determining progesterone levels in milk or blood may be the most efficient method for successful reproduction and yellow-body (corpus luteum) activity. Determination of progesterone levels in milk or serum between days 18 and 24 after artificial insemination is an immunological method, thus an indirect way to determine the pregnancy status in animals, including cows (Shearer, 1992; Parkinson et al., 1994; Prvanović et al., 2009).

Farmers need to accurately distinguish pregnant and non-pregnant cows in a herd as early as possible after insemination, allowing for rebreeding of non-pregnant animals with minimum delay (Patel et al., 2016). Open cows in herds affect profitability through additional expenditures and reduced incomes for farmers. Reduced income occurs as a result of lengthened calving intervals, lower inputs or outputs, fixed costs ratios (Sol and Renkema, 1984), reduced milk yield, loss of calf crop, increased labour, increased veterinary intervention and treatment costs, and increased culling rates of cows (Bellows and Short, 1994).

The aim of this this study was to assess the efficiency of a rapid test that measures progesterone level in milk in different breeds: Red Holstein, Black-Holstein, Simmental and local crossbreeds.

\section{Material and methods}

\section{Animals}

The study was carried in the Municipalities of Peja and Deçan, Kosovo. The our one-year study between 2017-2018 included 400 cows. Milk samples were taken from different cattle breeds as shown in Table 1 . The average age of cows varied from 3 to 9 years, and 
Table 1. Cows breeds used in the experiment

\begin{tabular}{|l|c|c|c|}
\hline Breed & Average age & $\begin{array}{c}\text { Average } \\
\text { lactation }\end{array}$ & $\begin{array}{c}\text { Number of } \\
\text { animals }\end{array}$ \\
\hline Black Holstein & $3-5$ & $1-4$ & 100 \\
\hline Red Holstein & $3-4$ & $1-3$ & 100 \\
\hline Simmental & $2-9$ & $2-6$ & 100 \\
\hline Local crossbreeds & $2-9$ & $2-8$ & 100 \\
\hline Total animals included in the study & & & 400 \\
\hline
\end{tabular}

lactation stage varied between the first to eighth lactation. Prior to AI, cows were checked by rectal palpation to determine their reproductive status.

\section{Sample collection and progesterone measurement}

In the on-farm test, we used P4 Rapid (Ridgeway Science, UK). Milk samples were collected 10-15 minutes after milking, 21 days after insemination. Samples were mixed to distribute the fat and milk was drawn with a clean pipette included in the kit box to the bottom of the bulb and then added to the test tube, being cautious to keep the level of milk below the red line. Colour development was recorded after 5 minutes. The test results were read visually based on the intensity of the test line and the control line. According to the manufacturer's instructions, a low progesterone level is indicated when the test line is darker or

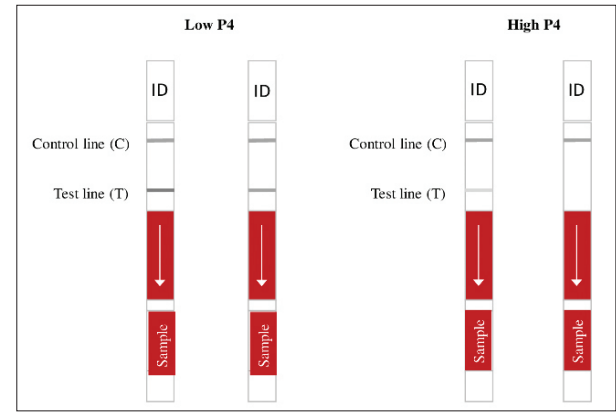

Figure 1. P4-test interpretation: low $\mathrm{P} 4 \mathrm{~T} \geq \mathrm{C}$; high $\mathrm{P} 4 \mathrm{~T}<\mathrm{C}$. same intensity as the reference line, while a high progesterone level is indicated when the test line is fainter than the reference line or is not visible (Fig. 1).

The sensitivity and specificity of the on-farm P4 test used in this study was previously evaluated by Waldman and Raud, (2016). Pregnancy confirmation was performed by per-rectal palpation. Several studies have indicated the potential risk of iatrogenic embryonic mortality when performing per-rectal pregnancy diagnosis in dairy cattle (White et al., 1989), and therefore in order to exclude any risks, and to ensure accuracy, animals were checked 60 days after insemination. Taking the economical aspect of our farmers into account, the present study focused only on these two methods for pregnancy detection.

\section{Statistical analysis}

Statistical analyses were processed with the program IBM SPSS Statistics. Ordinal Regression was calculated for detection of cows that did not become pregnant.

\section{Results and discussions}

From the conducted research on 400 cows included in the study, 69\% of cows tested as pregnant. These findings are in line with Howlader et al. (2019), who showed a similar and even higher percentage of conception rate after first AI based on cow age $(<2.5,2.5$ to 
$3.5,3.6$ to $4.5,4.6$ to $6,>6$ years with the respective conception rates $50 \%, 71.93 \%$, $78.06 \%, 85.49 \%, 74.52 \%)$. The remaining $31 \%$ cows of the included animals tested as non-pregnant 21 days after Artificial insemination. (Table 2). This result was confirmed through the rectal control 60 days after insemination.

According to Rhodes, (2005), pregnancy identification in non-bovine cows using progesterone levels in serum or milk is 95 to $100 \%$ accurate, while Chang and Estrergreen, (1983) reported an accuracy between $95-98.3 \%$ for nonbovine cows. In this study, of the 277 cows tested positive on day 21, 263 were confirmed positive on day 60 by rectal control, while 14 cows were finally diagnosed as non-pregnant.

Statistical analysis was performed by PLUM - Ordinal Regression Case Processing Summary (Table 3). The PLUM-summary reflects the percentage according to the types of cows that have not become pregnant.

The need of early pregnancy diagnosis is due to the extra costs incurred by delays in rebreeding arising from feeding the animal during low milk production, further loss occurs due to declining milk yield as a result of long colony intervals (Ball et al., 2004). Reproductive costs can be defined as all management costs including labour for synchronization treatment and insemination, and the cost of hormones, semen, and first and repeated pregnancy diagnosis tests, all aimed at impregnation of cows (Cabrera, 2016). Therefore, onfarm milk progesterone measurement offers veterinarians and farmers a rapid test to evaluate the reproductive status of a lactating cow (Dobranić et al., 2006; Waldmann and Raud, 2016). This will result in improved reproductive efficiency without additional investments, and will reduce reproductive costs per cow and per herd. Purohit, (2010) reported that the accuracy of pregnancy diagnosis using a progesterone test between 19-21 days after insemination is usually only about $80 \%$, whereas Chang and Estergreen (1983) consider it is 67.2 to $87.5 \%$. On the other hand, Fricke et al. (2002) reported that 10 to $16 \%$ cows diagnosed as pregnant at 28 days after insemination had lost their pregnancy by day 56 after conception.

A reason for the diagnosis of 123 cows as non-pregnant on day 21 after AI could be that the majority of embryonic mortality is early, before day 16 following breeding. In high-producing dairy cows, embryo loss can be as high as $50 \%$ in the first 7 days (Sartori et al., 2010). The issue of late embryo and early

Table 2. Pregnancy status of inseminated cows for the tested breeds on Day 21

\begin{tabular}{|l|c|c|c|c|c|}
\hline Status on D21 & $\begin{array}{c}\text { Black } \\
\text { Holstein }\end{array}$ & $\begin{array}{c}\text { Red } \\
\text { Holstein }\end{array}$ & Simmental & $\begin{array}{c}\text { Local } \\
\text { Crossbreeds }\end{array}$ & Total \\
\hline Pregnant & 62 & 64 & 72 & 79 & 277 \\
\hline Non- pregnant & 38 & 36 & 28 & 21 & 123 \\
\hline
\end{tabular}

Table 3. PLUM - Ordinal Regression: Number of positive diagnosed cows on D 60 for the tested breeds

\begin{tabular}{|l|c|c|c|c|}
\hline Day & Black Holstein & Red Holstein & Simmental & $\begin{array}{c}\text { Country } \\
\text { Crossbreeds }\end{array}$ \\
\hline D 21: 277 & 62 & 64 & 72 & 79 \\
\hline D 60: 263 & 56 & 60 & 70 & 77 \\
\hline
\end{tabular}


foetal mortality after about day 24 and 84 of gestation is also important (Silke et al., 2001). Horan et al. (2004) recorded an overall late embryo/foetal loss rate of $7.5 \%$ between days 30 and 67 of gestation in dairy cows managed in pasture-based production systems. The present study gives comparable results, since 14 cows (approx. 5\%) were diagnosed as nonpregnant after rectal control 60 days after AI, which is reasonable given that different cattle breeds were included (Table 3).

A large number of Holstein (38) and Red Holstein (36) diagnosed as non-pregnant on day 21 after AI might be related to their performance as high-producing dairy cows, as embryo survival appears to be lower in these breeds (Crowe et al., 2018). This is likely due to the increased involvement of body resources towards milk production, which reduces and depletes successful embryo development compared to Simmental and local crossbreeds that have lower milk production. However, other factors can also count for miscarriages, such as abnormalities that account for approximately $10 \%$ of embryonic losses within the first two weeks (King, 1985), chromosomal defects, or individual genes and genetic interactions (Van-Raden and Miller, 2006). As a genetic cause, several reproductive traits that are adversely affected by inbreeding could also contribute to embryonic losses, although the percentage of inbreeding and embryo transfers has decreased the embryonic abnormalities in cows (Van-Raden and Miller, 2006). The corpus luteum, as a transitory and dynamic formation regulated at different levels of transcription and post-transcription (Gecaj et al., 2017), produces the hormone progesterone that is absolutely essential in regulating endometrial function and it is important for successful establishment of pregnancy in cattle (Lonergan and Forde, 2015). As shown by several studies, there is a positive linear association between the progesterone concentration on the day of $\mathrm{PGF}_{2 \alpha}$ induced luteolysis and subsequent embryo survival rate (Diskin et al., 2006; Brooks et al., 2014). Other important factors in this respect are the feeding and breeding conditions of the cows on the farm (Mehmedi et al., 2012). As shown by Thiruvenkadan et al. (2010), most variations in fertility are determined by non-genetic factors or environmental factors. Nutritional causes are well known factors that play a role in pregnancy success. Reproductive performance decreases in high producing dairy cows, especially when animals are under a severe negative energy balance (Nebel and McGilliard, 1993; Folnožić et al., 2015; Folnožić et al., 2019). For all systems of milk production, more balanced breeding strategies must be developed with a greater emphasis on fertility and feed intake and/or energy balance (Diskin and Morris, 2008; Đuričić et al., 2020b).

\section{Conclusions}

Early pregnancy diagnosis is part of good management and helps to maximize reproductive performance. It is also directly associated with the production of animals and thereby the economic aspect for farmers. Improved reproductive performance increases overall herd economic net returns. From the results obtained in this study, we can recommend the use of progesterone $\mathrm{P} 4$ rapid test for early pregnancy diagnosis 21 days after AI on all lactating cows on a farm. It is a rather simple and stressfree for cows, and provide quick results, so that pregnancy can be continually monitored and tracked on a daily basis.

Additionally, research is needed to determine if these simple, quick, and accurate tests for determining relative milk progesterone concentrations will improve the reproductive efficiency and profitability of dairy herds. In addition, further efforts should be made to 
provide appropriate strategies that can be implemented on a greater number of farms, especially larger ones. To confirm pregnancy, we recommend per-rectal palpation as the least expensive method.

\section{References}

1. BALL, P. J. H. and A. R. PETERS (2004): Pregnancy diagnosis. In: Reproduction in cattle. $3^{\text {rd }} \mathrm{Ed}$. Blackwell publishing limited Oxford, United Kingdom.

2. BELLOWS, R. A. and R. E. SHORT (1994): Reproductive losses in the beef industry. In: Factors Affecting Calf Crop. Fields and Sands (Ed.). P. 109. (CRC Press, Boca Raton, FL.).

3. BROOKS, K., G. BURNS and T. E. SPENCER (2014): Conceptus elongation in ruminants: roles of progesterone, prostaglandin, interferon tau and cortisol. J. Anim. Sci. Biotechnol. 5, 53.

4. CABRERA, V. E. (2014): Economics of fertility in high-yielding dairy cows on confined TMR systems. Animal 8, 211-221.

5. CABRERA, V. E. (2016): Fertility associated economic losses of farms. $4^{\text {th }}$ Health Management \& Symposium 25-28 May. Maritim Pine Beach Otel - Antalaya, Turkey,

6. CHANG, C. F. and V. L. ESTERGREEN (1983): Development of a direct enzyme immunoassay of milk progesterone and its application to pregnancy diagnosis in cows. Steroids 41, 173-195.

7. CROWE, M. A., M. HOSTENS and G. OPSOMER (2018): Reproductive management in dairy cowsthe future. Irish Vet. J. 71, 1.

8. DISKIN, M. G. and D. G. MORRIS (2008): Embryonic and early foetal losses in cattle and other ruminants. Reprod. Domest. Anim. 43 Suppl 2, 260-267.

9. DISKIN, M. G., J. J. MURPHY and J. M. SREENA (2006): Embryo survival in dairy cows managed under pastoral conditions. Anim. Reprod. Sci. 96, 297-311.

10. DOBRANIĆ, T., P. KOČILA, M. SAMARDŽIJA, Z. MAKEK, A. TOMAŠKOVIĆ, I. GETZ, N. PRVANOVIĆ and S. VINCE (2006): Einfluss des endogenen und exogenenProgesterons auf den Verlauf und Ausgang der TrächtigkeitbeiKühen. Tierärtzl. Umsch. 61, 291-296.

11. ĐURIČIĆ, D., S. VINCE, M. LOJKIĆ, S. JELUŠIĆ, R. TURK, H. VALPOTIĆ, D. GRAČNER, N. MAĆEŠIĆ, I. FOLNOŽIĆ, Z. ŠOSTAR and M. SAMARDŽIJA (2020a): Effects of dietary clinoptilolite on reproductive performance, serum progesterone and insulin-like growth factor- 1 concentrations in dairy cows during pregnancy and lactation. Pol. J. Vet. Sci. 23, 69-75.

12. ĐURIČIĆ, D., B. BEER LJUBIĆ, S. VINCE, R. TURK, H. VALPOTIĆ, I. ŽURA ŽAJA, N. MAĆEŠIĆ, M. BENIĆ, I. GETZ and M. SAMARDŽIJA (2020b): Effects of dietary clinoptilolite supplementation on $\beta$-hydroxybutirate serum level and milk fat to protein ratio during early lactation in Holstein-
Friesian cows. Micropor. Mesopor. Mat. 292, 109766.

13. FRICKE, P. M. (2002): Scanning the future Ultrasonography as a reproductive management tool for dairy cattle. J. Dairy Sci. 85, 1918-1926.

14. GECAJ, R.M., C.I.SCHANZENBACH, B. KIRCHNER, M. W. PFAFFL, I. RIEDMAIER, R. Y. TWEEDIECULLEN and B. BERISHA (2017): The dynamics of microRNA transcriptome in bovine corpus lutem during its formation, function and regression. Front. Genet. 8:213.

15. HOWLADER, M. M. R., N. M. RAHMAN, M. G. HOSSAIN and M. A. HAI (2019): Factors Affecting Conception Rate of Dairy Cows Following Artificial Insemination in Selected Area at Sirajgonj District of Bangladesh. Biomed. J. Sci. \& Tech. Res. 13. BJSTR. MS.ID.002386.

16. KING, W. A. (1985): Intrinsic embryonic factors that may affect survival after transfer. Theriogenology 23, 161-174

17. KLECZKOWSKI, M., W. KLUCIŃSKI, M. CZERSKI and E. KUDYBA (2017): Association between acute phase response, oxidative status and mastitis in cows. Vet. stn. 48, 177-186.

18. KOČILA, P., M. SAMARDŽIJA, T. DOBRANIĆ, D. TOMISLAV, D. GRAČNER, V. DOBRANIĆ, N. PRVANOVIĆ, Ž. ROMIĆ, N. FILIPOVIĆ, N. VUKOVIĆ and D. ĐURIČIĆ (2009): Einfluss der Energiebilanz auf die Reproduktionsfähigkeit von Holsteiner Kühen im Puerperium. Tierärztl. Umsch. 64, 471-477.

19. LONERGAN, P. and N. FORDE (2015): The role of progesterone in maternal recognition of pregnancy in domestic ruminants. Adv. Anat. Embryol. Cell Biol. 216, 87-104.

20. MEHMEDI, B., L. TURMALAJ, T. KASTRATI and G. MOKA (2012): Cow artificial insemination at fixed time. Albanian K. Agric. Sci. Special edition: 2218-2020.

21. NEBEL, R. L. and M. L. McGILLIARD (1993): Interactions of high milk yield and reproductive performance in dairy cows. J. Dairy Sci. 76, 32573268.

22. PARKINSON, T. J., A. TUVEY and L. J. JENNER (1994): A morphometric analysis of the corpus luteum of the cow during the estrous cycle and early pregnancy. Theriogenology 41, 1115-1126.

23. PRVANOVIĆ, N., A. TOMAŠKOVIĆ, J. GRIZELJ, P. KOČILA and M. SAMARDŽIJA (2009): Monitoring of early pregnancy and early embryonic mortality by ultrasound and determination of PAG and progesterone in cows. Vet. arhiv 79, 259-267.

24. PUROHIT, G. (2010): Methods of Pregnancy Diagnosis in Domestic Animals: The Current Status. http://www.webmedcentral.com/wmcpdf/ Article_WMC001 305.pdf (accessed 21 October 2013). Webmed Central Reproduction 1, 1-26.

25. RHODES, R. C. (2005): The use of milk progesterone assays for reproductive management. Dairy integrated reproductive management IRM-9. Pp.1-4.

26. ROMANO, J. E., J. A. THOMPSON, D. W. FORREST, M. E. WESTHUSIN, M. A. TOMASZWESKI and D. C. KREAMER (2006): Early pregnancy diagnosis 
by transrectal ultrasonography in dairy cattle. Theriogenology 66, 1034-1041.

27. SARTORI, R., M. R. BASTOS and M. WILTBANK (2010): Factors affecting fertilization and early embryo quality in single- and superovulated dairy cattle. Reprod. Fertil. Dev. 22, 151-158.

28. SHEARER, J. K. (1992): The milk progesterone test and its application in dairy cattle reproduction. Dairy Production Guide. Fact Seet DS 60 sept.

29. SILKE, V., M. G. DISKIN, D. A. KENNY, M. P. BOLAND, P. DILLON, J. F. MEE and J. M. SREENAN (2001): Extent, pattern and factors associated with late embryonic loss in dairy cows. Anim. Reprod. Sci. 15, 1-12.

30. SOL, J. and A. RENKEMA (1984): A three year herd health and management program on the thirty Dutch dairy farms. I. Culling strategy and losses caused by the forced replacement of the dairy cows. Vet. Quart. 6, 141-148.

31. SZENCI, O., Z. SZELÉNYI, L. LÉNÁRT, D. BUJÁK, L. KOVÁCS, L. F. KÉZÉR, B. HAN and
A. HORVÁTH (2018): Importance of monitoring the peripartial period to increase reproductive performance in dairy cattle. Vet. stn. 49, 297-307.

32. THIRUVENKADAN, A. K., S. PANNEERSELVAM, R. RAJENDRAN and N. MURALI (2010): Analysis on the productive and reproductive traits of Murrah buffalo cows maintained in the coastal region of India. Appl. Anim. Husb. Rural Dev. 3, 1-5.

33. VanRADEN, P. M. and R. H. MILLER (2006): Effects of non-additive genetic interactions, inbreeding and recessive defects on embryo and fetal loss by seventy days. J. Dairy Sci. 89, 2716-2721.

34. WALDMANN, A. and A. RAUD (2016): Comparison of a lateral flow milk progesterone test with enzyme immunoassay as an aid for reproductive status determination in cows. Vet. Rec. 178, 260.

35. YOUNGQUIST, R. C. (2007): Pregnancy diagnosis. In: Youngquist, R. C., Threlfall, W. R., eds. Current Therapy in Large Animal Theriogenology. $2^{\text {nd }}$ ed. St-Louis: Saunders. Pp. 294-303.

\section{Praktična primjena brzog progesteronskog P4 testa za rano otkrivanje gravidnosti iz kravljeg mlijeka}

Dr. sc. Blerta MEHMEDI, dr. med. vet., asistentica za istraživanje i nastavu, dr. sc. Rreze M. GECAJ, docent, Poljoprivredni i Veterinarski fakultet, Univerzitet u Prištini, Republika Kosovo; dr. sc. Taulant KASTRATI, dr. med. vet., direktor Veterinarskog servisa Kosova, Republika Kosovo; dr. sc. Miklós HELTAI, redoviti profesor, Fakultet poljoprivrednih i okolišnih znanosti, Univerzitet Szent István, Mađarska; dr. sc. Luigj TURMALAJ, dr. med. vet., redoviti profesor, Veterinarski fakultet, Poljoprivredno sveučilište Tirana, Albanija

Dijagnoza gravidnosti bitan je dio menadžmenta plodnosti u goveda. Rana dijagnostika gravidnosti 21 dana nakon osjemenjavanja omogućava rano prepoznavanje i ponovno umjetno osjemenjivanje (UO) negravidnih krava s minimalnim produžetkom servisnog razdoblja te je od ekonomskog interesa za poljoprivrednike. Brzi progesteronski $\mathrm{P} 4$ testovi puno se koriste $\mathrm{u}$ strategijama upravljanja plodnosti, ali postoji ograničen broj podataka o učinkovitosti tih testova za mjerenje P4 iz kravljeg mlijeka. Mjereći koncentraciju progesterona P4 iz mlijeka različitih pasmina krava kao što su: crveni holstein, crni holstein, simentalska pasmina i lokalne križane pasmine, ova studija ima za cilj procjenu praktične primjene $i$ učinkovitosti ranog i brzog testa dijagnostike gravidnosti iz kravljeg mlijeka. Studija je provedena u razdoblju od 2017. i 2018., a uzorci mlijeka uzorkovani su životinjama 21. dana nakon UO u svrhu dijagnostike gravidnosti. Od 400 krava uključenih u ovo istraživanje, interpretacijom rezultata na temelju uporabe progesteronskog P4 brzog testa (Ridgeway Science, VB) $69 \%$ testiranih krava je bilo gravidno, dok $31 \%$ krava nisu bile gravidne. Točnost rane dijagnoze potvrđena je 60 dana nakon UO krava (bez daljnjih UO krava) rektalnom palpacijom. Na temelju ovog ispitivanja 263 krave, odnosno njih $66 \%$ je dijagnosticirano gravidnima, dok 14 krava ili $34 \%$ nisu bile gravidne. Najveća preciznost $\mathrm{u}$ otkrivanju gravidnosti ovom metodom ustvrđena je u lokalnih križanih pasmina i krava simentalske pasmine $\mathrm{s}$ $97 \%$ točno dijagnosticiranih krava, a slijede ih pasmina crveni holstein s $94 \%$ i crni holstein s $90 \%$ točnosti. Naše istraživanje pokazalo je da se s preciznošću od $90 \%$ do $97 \%$ za različite testirane pasmine krava uporaba brzih progesteronskih $\mathrm{P} 4$ testova u uzorcima mlijeka pokazala učinkovitom, brzom i točnom metodom za rano otkrivanje gravidnosti krava.

Ključne riječi: umjetno osjemenjivanje, gravidnost, screening test, rektalna pretraga 